\title{
Monetary Policy and Financial Asset Prices: Empirical Evidence from Pakistan
}

\author{
Imran Umer Chhapra ${ }^{1}$, Muhammad Usama Ali ${ }^{2}$, Syeda Fizza Zehra ${ }^{3}$, Falak $\mathrm{Naz}^{4}$
}

\begin{abstract}
Monetary transmission mechanism assumed to be significantly influenced by the effect of policy decisions on financial markets. However, various previous studies have come up with different outcomes. The purpose of this study is to examine the impact of monetary policy on different asset classes (shares and bonds) in Pakistan. This study using stock price and bond yield as dependent variable and discount rate, money supply, inflation, and exchange rate are independent variables. Data of all variables have collected from 2010 to 2016, and Vector Autoregressive (VAR) technique has applied. The empirical results indicate that there is an impact of monetary policy components on both stock and bond market as an increase in policy rate causes decline in stocks prices and bonds yields. The findings of this study will help the potential investors in making long-term (in general) and short-term (in particular) investment strategies concerning monetary policy.
\end{abstract}

Keywords: monetary policy, asset prices, financial markets

\begin{abstract}
Abstrak
Mekanisme transmisi moneter diasumsikan sangat dipengarubi oleh pengaruh keputusan kebijakan di pasar keuangan. Namun, berbagai penelitian sebelumnya telah menghasilkan hasil yang berbeda. Tujuan dari penelitian ini adalah untuk menguji dampak kebijakan moneter terhadap berbagai kelas aset (saham dan obligasi) di Pakistan. Untuk mempelajari dampak ini, harga saham dan imbal hasil obligasi telah diambil sebagai variabel dependen dan tingkat diskonto, jumlah uang beredar, inflasi dan nilai tukar merupakan variabel bebas. Data semua variabel telah dikumpulkan dari teknik 2010 sampai 2016 dan Vector Autoregressive (VAR) telah diterapkan. Hasil empiris menunjukkan bahwa ada penurunan harga saham dan imbal hasil obligasi. Temuan penelitian ini akan membantu calon investor dalam membuat strategi investasi jangka panjang (secara umum) dan jangka pendek (khususnya) sehubungan dengan kebijakan moneter.
\end{abstract}

Kata Kunci: kebijakan moneter, harga aset, pasar keuangan

How to Cite:

Chhapra, I. U., Ali, M. U., Zehra, S. F., \& Naz, F. (2018). Monetary Policy and Financial Asset Prices: Empirical Evidence from Pakistan. Signifikan: Jurnal Ilmu Ekonomi. Vol. 7 (2): 149 - 160. doi: http//dx.doi.org/10.15408/ sjie.v7i2.7099. 


\section{Introduction}

Impact of monetary policy on asset prices considered as one of the most debatable topics in the financial world. Studies have done on this topic and different researchers have come up with different outcomes. There is number of macroeconomic factors that affect the stock market and bonds. However, Black et al (1990) agree that monetary policy is not itself a sufficient tool to measure the booms and busts in the asset price. Well-designed legal accounting systems and fiscal policies that usually instill the confidence of the public in economic fundamentals are also vital components to insulate our economy from financial ups and downs. It further noted that asset price crashes had sustained damage to the economy when monetary policy was unresponsive or when reinforced deflationary pressure. Factors like inflation, exchange rate, money supply and discount rate played an important role in determining the monetary policy rate for an economy and thus might have an impact on different asset prices.

Financial markets, individually the stock market is considered to be a susceptible market that brings variations in the economy. Its prices may not specify the exact fundamentals of stock due to some of its macroeconomic variables (taxes) (Mustafa et al, 2013). Chirchir (2014) found that there is no significant causal relationship between interest rate and share price. Also, the amount of securities is comprehensively reliant on the transparency of the issuer's information to ensure that the market is effective and affordable (Jardet and Monks, 2014).

Moreover, bond yields also influenced by monetary policy (Goltz and Campani, 2011). Sensarma and Bhattacharyya (2016) further state that the impact of monetary policy is quite critical on interest rates due to its dominance over the aggregate level of investment and spending in the economy. The primary function of monetary policy is to control interest rates and define the risk-free rate of return, which has a better influence on the claim for numerous types of financial securities, including bonds. When interest rates are low, bond yields are falling as demand for bonds rises (Sharma and Sinha, 2006).

The important question arises here is the understanding of monetary policy. Monetary policy takes into account the central bank's actions that determine the rate and size of growth of money supply in any economy. The objectives of monetary policy are evident regarding macroeconomic variables like inflation, money supply, exchange rate and real output and it maintained through actions like buying and selling government bonds and modifying interest rates. At a broad level there are mainly two type of monetary policies, there are: contractionary and expansionary policy. Expansionary policy involves increasing the money supply to reduce the unemployment rate and simultaneously expanding the consumer spending and private-sector borrowing. This activity helps in stimulating the economic growth of the economy. In the same context, reducing the money supply, on the other hand, implies contractionary policy. This action helps to curb inflation (Ioannidis and Kontonikas, 2008). However, it adversely affects the economic growth as it paves the way to unemployment, depresses the spending and borrowing by businesses and customers. This fact could result in recession as well (Ioannidis and Kontonikas, 2008). So, 
the understanding of monetary policy and its impact on economic output is essential for the economic growth of a country.

Arrelano and Bond (1991) summarizes that the impact of anticipated and unanticipated monetary policy on stock return. In this regard, Bernanke and Kuttner (2005) pointed out that while examining the relationship between monetary policy changes and stock returns. In anticipated monetary policy there is a possibility that market participants might have already incorporated anticipated policy actions into their investment decisions. While using Kutner's (2001) future methodology, it was concluded by Bernanke and Kuttner (2005) which tightening an unanticipated monetary policy exerts an adverse impact on the stock market. Their findings were consistent with the concept that the contracts of loan take time to be adjusted. Nevertheless, it is proven by them that an increase in the minimum rediscount rate (MRR) would pressurize banks to cut down loan amount that they lend to the customers.

Another study is conducted to understand the effects of monetary policy and fiscal policy on the stock market done by Hsing (2005). This study uses interest rate and debt ratio to analyze their impact on Poland's stock market index. He suggested that there is a negative impact on debt ratio to GDP and interest rate. Konrad (2009) found a positive correlation between the US and German stock market performances. Moreover, early efforts of Cook and Han (1989), found that Treasury bill returns significantly respond to changes in Fed rates in 1970's. Edelberg and Marshall (1996) argue that there is no significant response found. Later, Evans and Marshall (1998) added on that long-term interest rates are not affected by policy rates if the maturity is more than ten years. Sellon and Roley (1995), found that rise in Fed rates is statistically insignificant with long-term government bonds rates. This result indicates that long-term rates responded over the period and market perceptions. On the other hand, Ludvigson et al. (2002), found the impact of Fed rates is significant but temporary. Further Beechey (2007), Kuttner (2001), and Gurkaynak et al. (2002) studied that how Fed rates effects the other market rates.

Similarly, D’Amico and King (2013), Gagnon et al. (2011), Krishnamurthy and Vissing-Jorgensen (2011) conclude that there is a positive impact of policy rates on securities prices. On the other hand, Dowing (2001) found with the findings that when Fed reserves enter into the policy tightening cycle, it increases the risk premium of commercial paper and issuers of documents modify the maturities of paper by doing buy (sell). Later, Jayadev and Kumar (2004) studied the same relationship by using Error correction model (ECM) and regression model and found that there is a significant relationship between both the rates but not reflected rapidly.

It can be concluded that many studies have found that the monetary transmission mechanism is rapid and effective (Taboga, 2009). However, many other studies (Edelberg, and Marshall, 1996; Gourio, 2013; and Maio, 2014) have observed that the impact of monetary policy interest rates on market interest rates is uncertain both in developed and developing economies. Therefore, it generates the need to examine the impact monetary policy on asset prices in the context of developed and developing economies. About 
Pakistan's context, very few researches have been conducted to analyze the impact of monetary policy on financial assets prices. The most important thing is that they have mostly covered the period till 2013 with the different theoretical framework. However, after 2013, Pakistan has seen a continuous decreasing trend to its monetary policy rate. So it is important to understand the impact of monetary policy on Pakistan's economy since 2013. Therefore, in our research, we have inculcated the period from 2010 to 2016. In this study, two crucial financial assets (shares and bonds) have been used to examine the impact of monetary policy on Pakistan's economy. The study purely based on Pakistan market, and the findings of this paper essentially help the potential investors in making their longterm (in general) and short-term (in particular) investment strategies when it comes to the impact of monetary policy on financial asset classes which includes stock and bond. Moreover, the study highlights the critical factors that have the significant impact on stock and bond prices in Pakistan. The research can also be used as a base for the prospective work in the capital market industry.

\section{Method}

This study is going to examine the impact of monetary policy on stock and bond prices. This research used a secondary data from January 2010 to December 2016. Pakistan has seen a continuous decreasing trend in monetary policy rate whereas, in the stock market, KSE-100 index had reached its peak. The bond market also fluctuates very slowly during this period. Stock and bond market data is collected from official websites of PSX, MUFAP, and SBP respectively. Whereas, monetary policy components (discount rate, consumer price index, exchange rate, and money supply) gathered through SBP, Bloomberg, and Thomson Reuters DataStream databases. Furthermore, stock price and bond yield have been taken as dependent variable whereas independent variables include the discount rate, money supply, inflation, and exchange rate.

Although researchers have conducted in the past regarding the impact, the impact monetary policy on different investment instruments but the uniqueness of this research is that we have the used the Vector Autoregressive (VAR) model to check the impact of monetary policy components on stock and bond prices. The model used mainly due to the following reasons: there are no exogenous variables all variable are endogenous, thus provides a better result, VAR allow variables to depend on its lag that provides flexibility as compared to univariate models. Lastly, VAR is used to measure the relationship between economic and market variables. This research aims to examine the long run cointegration relationships between stock and bond market with monetary policy instruments. So, following are the base estimating equation to examine the impact in the log-linear form:

$$
\begin{aligned}
& \ln \left(K S E-100_{t}\right)=\alpha_{t}+\beta \ln \left(D R_{t}\right)+\gamma \ln \left(C P I_{t}\right)+\psi \ln \left(M S_{t}\right)+\Omega \ln \left(E R_{t}\right)+\varepsilon_{t} \\
& \ln \left(10 Y-P I B_{t}\right)=\alpha_{t}+\beta \ln \left(D R_{t}\right)+\gamma \ln \left(C P I_{t}\right)+\psi \ln \left(M S_{t}\right)+\Omega \ln \left(E R_{t}\right)+\varepsilon_{t}
\end{aligned}
$$

Where, $K S E-100=$ stock market indices of Pakistan, $10 y-P I B=10$ year Pakistan investment bond yield, $D R=$ discount rate, $M S=$ money supply, $C P I=$ consumer price index and $E R=$ exchange rate. 
The reason behind the conversion of a variable into natural logs is that if variables are in the log, the cointegration vector can interpret as long-term elasticities. Another reason for conversion into the natural $\log$ is that the first difference can be interpreted as growth rates if data is in log-normal form. The error term is independently and identically (iid) distributed and $\mathrm{t}$ is used for the period. To execute the research, initially, descriptive statistics have been run which describes the basic features of data. Then to eliminate the issue of spurious regression, the stationarity of data have tested through Augmented Dickey and Fuller (ADF) test, Phillips and Perron (PP) test, Kwiatkowski (KPSS) test. To test the co-integration relationship among variables and possibility of long-run equilibrium relationship in case of non-stationarity of data, the co-integration test with Engel-Granger method has been used to overcome the problem of spurious correlation. Finally, the Vector Autoregressive (VAR) is an econometric gauge that is utilized to examine the linear association of numerous factors in a panel time series data with each other. The separate test has been run with KSE100 (stock) and PIB 10 year (bond) with the independent variables. The VAR model that is used in this research paper can be specified as follows:

$$
\begin{aligned}
\Delta \operatorname{lnKSE100_{t}=} & \alpha+\sum_{i=1}^{n} b_{i} \Delta K S E 100_{t-1}+\sum_{i=1}^{m} c_{i} \Delta D R_{t-1}+\sum_{i=1}^{k} d_{i} \Delta C P I_{t-1} \\
& +\sum_{i=1}^{l} e_{i} \Delta M S_{t-1}+\sum_{i=1}^{o} c_{i} \Delta E R_{t-1} \\
\Delta \operatorname{lnPIB10Y} Y_{t}= & \alpha+\sum_{i=1}^{n} b_{i} \Delta P I B 10 Y_{t-1}+\sum_{i=1}^{m} c_{i} \Delta D R_{t-1}+\sum_{i=1}^{k} d_{i} \Delta C P I_{t-1} \\
& +\sum_{i=1}^{l} e_{i} \Delta M S_{t-1}+\sum_{i=1}^{o} c_{i} \Delta E R_{t-1}
\end{aligned}
$$

After model estimation, residual diagnostic tests are conducted to guarantee the strength of the results and to confirm normality; the model satisfies homoscedasticity and no serial correlation of the residuals assumptions.

\section{Results and Discussion}

Descriptive statistics are used to describe the basic characteristics of data. The value of skewness in Table 1 is low and negative indicating all variables data are negatively skewed. Moreover, kurtosis value is below its normal benchmark 3 (normal distribution) that confirms the data is near normal. The ratio between mean to the median of the variables are close to 1 . Standard deviation also comes out to low.

In order to assess the stationarity of data, KPSS (Kwiatkowski-Phillips-Schmidt-Shin), PP (Phillips Peron test statistic), and ADF (Augmented Dickey Fuller test statistic) have been used. The optimum length of lag in ADF has been estimated with Schwarz criterion as the default. 
Table 1. Descriptive Statistics

\begin{tabular}{lcccccc}
\hline & KSE 100 & PIB & DR & CPI & ER & MS \\
\hline Mean & 9.912 & 2.436 & 2.274 & 5.173 & 4.583 & 15.940 \\
Median & 9.991 & 2.516 & 2.303 & 5.203 & 4.591 & 15.974 \\
Std. Dev. & 0.494 & 0.188 & 0.268 & 0.143 & 0.068 & 0.269 \\
Skewness & -0.078 & -0.736 & -0.379 & -0.585 & -0.630 & -0.099 \\
Kurtosis & 1.484 & 2.101 & 1.905 & 2.150 & 2.277 & 1.827 \\
\hline
\end{tabular}

Table 2 shows that LnKSE100, LnPIB, LnDR, LnER and LnMS are non-stationary at level. However, LnCPI value comes out less than 5\% that reject the null hypothesis of nonstationarity and accept the alternative hypothesis of stationarity. Moreover, stationarity of all the variables has restored at 1 st differencing level except MS. On the other hand, stationarity for the variable MS can restore at 2nd differencing. Precisely, the ADF, PP, and KPSS test decisively confirm the non-stationarity of each variable at levels and conclude that series is stationary at the 1 st difference (See Table 3).

Table 2: Unit Root Test Analysis at Level

\begin{tabular}{lcccccc}
\hline & \multicolumn{2}{c}{ ADF } & \multicolumn{2}{c}{ PP } & \multicolumn{2}{c}{ KPSS } \\
& \multicolumn{2}{c}{ Test for I(0): Level } & \multicolumn{2}{c}{ Test for I(0): Level } & \multicolumn{2}{c}{ Test for I(0): Level } \\
& P-value & Decision & P-value & Decision & P-value & Decision \\
\hline Ln KSE100 & 0.954 & Non-stationary & 0.967 & Non-stationary & 1.140 & Non-stationary \\
Ln PIB & 0.940 & Non-stationary & 0.921 & Non-stationary & 0.885 & Non-stationary \\
Ln DR & 0.928 & Non-stationary & 0.968 & Non-stationary & 1.140 & Non-stationary \\
Ln CPI & 0.008 & Non-stationary & 0.004 & Non-stationary & 1.121 & Non-stationary \\
Ln ER & 0.417 & Non-stationary & 0.423 & Non-stationary & 1.016 & Non-stationary \\
Ln MS & 0.635 & Non-stationary & 0.939 & Non-stationary & 1.157 & Non-stationary \\
\hline
\end{tabular}

Table 3. Unit Root Test Analysis at First Difference

\begin{tabular}{lcccccc} 
& \multicolumn{2}{c}{ ADF } & \multicolumn{2}{c}{ PP } & \multicolumn{2}{c}{ KPSS } \\
& \multicolumn{2}{c}{ Test for I(1): 1 $^{\text {st }}$ Difference } & \multicolumn{2}{c}{ Test for I(1): 1 $^{\text {st }}$ Diff. } & \multicolumn{2}{c}{ Test for I(1): 1 $^{\text {st }}$ Diff. } \\
& P-value & Decision & P-value & Decision & P-value & Decision \\
\hline Ln KSE100 & 0.000 & Stationary & 0.000 & Stationary & 1.140 & Stationary \\
Ln PIB & 0.000 & Stationary & 0.000 & Stationary & 0.885 & Stationary \\
Ln DR & 0.001 & Stationary & 0.000 & Stationary & 1.140 & Stationary \\
Ln CPI & 0.000 & Stationary & 0.000 & Stationary & 1.121 & Stationary \\
Ln ER & 0.000 & Stationary & 0.000 & Stationary & 1.016 & Stationary \\
Ln MS & 0.157 & Non-stationary & 0.000 & Stationary & 1.157 & Stationary \\
\hline
\end{tabular}


After conducting stationarity analysis through ADF, PP and KPSS unit root tests of data, Johansen co-integration has been employed to test the long-term relationship of stock and bond prices with monetary policy components. To use this method lag length of the VAR is determined based on the Akaike Information Criterion (AIC). If a lag length is determined using AIC tests, the next step is to carry out an LM test for residual serial correlation with the hypothesis of no serial relationship at specific lag order. According to Johansen (1991), the VAR residuals should be uncorrelated for reliable results.

Table 4. Test of Co-integrating Relationship between Variables

\begin{tabular}{lccccc}
\hline No. of CE(s) & $\begin{array}{c}\text { Trace } \\
\text { Statistics }\end{array}$ & $\begin{array}{c}\text { Critical } \\
\text { Value }\end{array}$ & $\begin{array}{c}\text { Max-Eigen } \\
\text { Value }\end{array}$ & Critical Value & Decision \\
\hline Ho: None $^{*}$ & 85.252 & 95.753 & 34.241 & 40.077 & \\
Ho: At most 1 & 51.010 & 69.818 & 19.166 & 33.876 & $\begin{array}{c}\text { No } \\
\text { Ho: At most 2 }\end{array}$ S1.844 $^{\text {Ho: At most 3 }}$ \\
\hline
\end{tabular}

* denotes rejection of the hypothesis at the 0.05 or 0.1 level

Table 4 explains the Unrestricted Co-integration Rank Test (Trace \& Maximum Eigenvalue). On the basis of above results, we fail to reject null hypothesis as both Trace statistics and Eigenvalue are less than their respective critical values at 5\% level of significance explaining no long run relationship of stocks and bond prices with monetary policy in Pakistan. So, as no co-integration exist between assets prices and monetary policy in Pakistan we Vector Error Correction Model cannot applied therefore, VAR technique has been used to check the short term relationship.

Table 5. Diagnostic Tests

\begin{tabular}{ccc}
\hline Serial Correlation & Heteroskedasticity & Normality \\
\hline Obs $R$-Squared $=11.107$ & Obs R-Squared $=13.850$ & Jarque Bera $=0.944$ \\
$P$ value $=0.087$ & P value $=0.743$ & P value $=0.813$ \\
\hline
\end{tabular}

The results of diagnostic tests are reported in Table 5 to indicate that the error term normally distributed as the p-value is greater than $0.05(0.813>0.05)$ at $5 \%$ level of significance. Hence, we fail to reject null hypothesis and conclude that error term is normally distributed. The result of serial correlation LM test shows that there is no serial correlation in the model as that Obs-R squared is equal to 11.107 and $\mathrm{p}$-value is greater than $0.05(0.087$ $>0.05)$. Lastly, a diagnostic test for Heteroscedasticity in the remaining term of the model reveals that model is homoscedastic as its p-value is higher than $0.05(0.743>0.05)$. Hence, after diagnostic analysis, it can be concluded that our model is robust and has BLUE (Best Linear Unbiased Estimates) of the coefficients.

The Vector Autoregressive is a statistical estimate that is applied to assess any linear 
interdependence among some variables especially in a data of time series nature. The top depicts coefficient of dependence while the next value indicates standard errors in the data and proceeding values report $t$-statistics for interdependence among variables. The lower portion of both tables (Table 6 and 7) shown above appraised that multiple time series assessment using two lag values at -1 and -2 are significantly related to another variable. The amount of R-squared is 0.89 for the variable "KSE100 (stock)" and 0.86 for the variable "PIB (bonds)" which showed that there is substantial interdependence between time series estimates proving that there is a significant impact of monetary policy components on stock and bond prices. Similar results found by Maio and Philip (2015). High F-statistic also proves this claim regarding the impact of monetary policy on asset prices.

Table 6. VAR Estimates: KSE100

\begin{tabular}{ccccc}
\hline Variable & Coefficient & Std. Error & t-Statistic & Prob. \\
\hline KSE100(-1) & 0.7600 & 0.1200 & 6.4400 & 0.0000 \\
KSE100(-2) & 0.1100 & 0.1100 & 0.9800 & 0.3300 \\
DR(-1) & 0.0800 & 0.1700 & 0.4800 & 0.6300 \\
DR(-2) & -0.0400 & 0.1700 & -0.2600 & 0.8000 \\
CPI(-1) & 0.0600 & 0.7600 & 0.0700 & 0.9400 \\
CPI(-2) & -0.1300 & 0.7900 & -0.1600 & 0.8700 \\
ER(-1) & -0.7700 & 0.5000 & -1.5200 & 0.1300 \\
ER(-2) & 0.8900 & 0.4800 & 1.8500 & 0.0700 \\
MS(-1) & 1.3600 & 0.4400 & 3.0600 & 0.0000 \\
MS(-2) & -1.0700 & 0.4200 & -2.5200 & 0.0100 \\
Constant & -3.5600 & 1.9800 & 1.810 & 0.0000 \\
\hline$R^{2}=0.89$, Adj. $R^{2}=0.89$, F-stat $=877.66($ prob. $=0.000)$ & & & \\
\hline
\end{tabular}

Thus, to conclude it can say that there exists a significant relationship between bond and stock markets with the variations in discount rate, money supply, inflation, and exchange rate in Pakistan. In the stock analysis, it is evident that at the first lag, discount, inflation and money supply has a positive relationship with stock market whereas, exchange rate came out to be the negative relationship with the stock market. It is also evident that at the first lag, exchange rate, inflation, and money supply has a positive relationship with bond market whereas, discount rate came out to be the negative relationship with the bond market.

Our results are similar to Ioannidis and Kontonikas (2006), Taboga (2009), Mustafa, et al. (2013), Maio (2014) and. The results of VAR also suggest this impact to be true among stock market and bond market with monetary policy components. Past research by Sharma and Sinha (2006) have also observed similar kind of result in India that has an entirely 
identical economic system like Pakistan. Mukherjee and Naka (1995) studied the relationship between stock prices and macroeconomic variables and found a positive correlation between stock prices and other variables. In bonds, similar kind of relationship found in South Africa where Aziakpono and Wilson (2007). Similarly, Kelilume (2014) who conducted the study to observe the impact of policy rate on short-term rates and long-term rates in Nigeria found that monetary policy interest rate in Nigeria's short- and long-term retail interest rates is sticky.

Table 7. VAR Estimates: PIB10Y

\begin{tabular}{ccccc}
\hline Variable & Coefficient & Std. Error & t-Statistic & Prob. \\
\hline PIB10Y(-1) & 0.9500 & 0.1200 & 7.8500 & 0.0000 \\
PIB10Y(-2) & 0.0300 & 0.1400 & 0.2200 & 0.8300 \\
DR(-1) & -0.1000 & 0.1700 & -0.5600 & 0.5800 \\
DR(-2) & -0.0200 & 0.1600 & -0.1600 & 0.8800 \\
CPI(-1) & 1.6500 & 0.6300 & 2.6400 & 0.0100 \\
CPI(-2) & -1.4700 & 0.6500 & -2.2500 & 0.0300 \\
ER(-1) & 0.2600 & 0.4200 & 0.6200 & 0.5300 \\
ER(-2) & -0.1800 & 0.4000 & -0.4500 & 0.6500 \\
MS(-1) & 0.7400 & 0.3700 & 1.9900 & 0.0500 \\
MS(-2) & -0.9800 & 0.3500 & -2.8500 & 0.0100 \\
Constant & -2.8600 & 2.1900 & 1.3000 & 0.2000 \\
\hline
\end{tabular}

$R^{2}=0.86$, Adj. $R^{2}=0.86$, F-stat $=184.16($ prob. $=0.000)$

\section{Conclusion}

The purpose of this study is to analyze the impact of stock and bond market with the monetary policy components that include discount rate, inflation, money supply and exchange rate in Pakistan. The results indicate that there is a significant impact of monetary policy components on both stock and bond market especially during the years under review. The empirical results of the co-integration test indicate the absence of long-run relationship among the variables.

Governments should consider the changes in the rate of interest and speed of inflation as these indicators of macroeconomics have severe implications for the overall economy and economic growth. Stock and bond markets are a significant indicator of the economic stability of a country. Any government, to reflect a better image and invite investments from foreign sources, should interfere in stock market operations with the help of monetary tools, as these would impact the GDP growth rate as well as GDP per capita of the economy hence attracting foreign investors. 


\section{References}

Beechey, J. M. (2007). A Closer Look at The Sensitivity Puzzle: The Sensitivity of Expected Future Short Rates and Term Premia to Macroeconomic News. Divisions of Research and Statistics and Monetary Affairs: Federal Reserve Board, Washington, DC. 2

Bernanke, B., \& Kuttner, K. N. (2005). What Explains the Stock Market's Reaction to Federal Reserve Policy? Journal of Finance. Vol. 60: 1221-1257. doi: https://doi. org/10.1111/j.1540-6261.2005.00760.x

Black, F., Derman, E., \& Toy, W. (1990). A One-Factor Model of Interest Rates and Its Application to Treasury Bond Options. Financial Analyst Journal. Vol. 46 (1): 33-39.

Chircir, D. (2014). The Relationship Between Share Prices and Interest Rate: Evidence from Kenya. Journal of Finance and Investment Analysis. Vol. 3 (2): 91-98.

Cook, T., \& Hahn, T. (1989). The Effect of Changes in The Federal Funds Rate Target on Market Interest Rates in the 1970s. Journal of Monetary Economics. Vol. 24: 331351. doi: https://doi.org/10.1016/0304-3932(89)90025-1.

D’Amico, S., \& King, T. B. (2013). Flow and Stock Effects of Large-scale Treasury Purchases: Evidence on The Importance of Local Supply. Journal of Financial Economics. Vol. 108(2): 425-448. doi: https://doi.org/10.1016/j.jfineco.2012.11.007.

Edelberg, W., \& Marshall, D. (1996). Monetary Policy Shocks and Long-term Interest Rates. Federal Reserve Bank of Chicago Economic Perspectives. Vol. 20(2): 2-17.

Evans, C. L., \& Marshall, D. A. (1998). Monetary Policy and The Term Structure of Nominal Interest Rates: Evidence and Theory. Carnegie Rochester Series on Public Policy. Vol. 49(2): 53-111.

Gagnon, J., Raskin, M., Remache, J., \& Sack, B. (2011). The Financial Market Effects of The Federal Reserve's Large-Scale Asset Purchases. International Journal of Central Banking. Vol. 7(1): 3-43.

Goltz, F. \& Campani, C. H. (2011). A Review of Corporate Bond Indices: Construction Principles, Return Heterogeneity, and Fluctuations in Risk Exposures. Working paper. EDHEC - Risk Institute.

Gourio, F. (2013). Credit Risk and Disaster risk. American Economic Journal: Macroeconomics. Vol. 5(3): 1-34. doi: https://doi.org/10.1257/mac.5.3.1.

Gurkaynak, R. S., Sack, B. P., \& Swanson, E. T. (2004). Do Actions Speak Louder Than Words? The Response of Asset Prices to Monetary Policy Actions and Statements. Working Paper. Finance and Economics Discussion Series. Divisions of Research \& Statistics and Monetary Affairs. Federal Reserve Board.

Hsing, Y. (2005). Did U.S. Monetary Policy Respond to Exchange Rates, Long-Term Interest Rates, and the Unemployment Rate Gap? The International Trade Journal. Vol. 19(1): 67-82.

Ibrahim, M. H. (2003), Macroeconomic Variables and Stock Prices in Malaysia: An Empirical Analysis. Asian Economic Journal. Vol. 13 (2): 219 - 230. doi: https://doi. org/10.1111/1467-8381.00082. 
Ioannidis, C., \& Kontonikas, A. (2006). Monetary Policy and The Stock Market: Some International Evidence. Working Paper. Department of Economics, University of Glasgow

Ioannidis, C., \& Kontonikas, A. (2008). The Impact of Monetary Policy on Stock Prices. Journal of Policy Modeling. Vol. 30(1): 33-53. doi: https://doi.org/10.1016/j. polmod.2007.06.015.

Jardet, C., \& Monks, A. (2014). Euro Area Monetary Policy Shocks: Impact on Financial Asset Prices During The Crisis? Working papers 512. Banque de France.

Kelilume, I. (2014). Effects of The Monetary Policy Rate on Interest Rates in Nigeria. The International Journal of Business and Finance Research. Vol. 8(1): 45-55.

Konrad, E. (2009). The Impact of Monetary Policy Surprises on Asset Return Volatility: The Case of Germany. Financial Markets and Portfolio Management. Vol. 23: 111135. doi: https://doi.org/10.1007/s11408-009-0102-5.

Krishnamurthy, A., \& Vissing-Jorgensen, A. (2011). The Effects of Quantitative Easing on Interest Rates: Channels and Implications For Policy. Brookings Papers on Economic Activity. Vol. 2: 215-287.

Kuttner, K. N. (2001). Monetary Policy Surprises and Interest Rates: Evidence From The Fed Funds Futures Market. Journal of Monetary Economics. Vol. 2 (6): 523-544. doi: https://doi.org/10.1016/S0304-3932(01)00055-1.

Ludvigson, S., Steindel, C., \& Lettau, M. (2002). Monetary Policy Transmission Through The Consumption-Wealth Channel. New York Economic Policy Review, FRBNY. Vol. 2: 117-133.

Maio, P., (2014). Another Look at The Stock Return Response to Monetary policy Actions. Review of Finance. Vol. 18: 321-371.

Maio, P., \& Philip, D. (2015). Macro Variables and The Components of Stock Returns. Journal of Empirical Finance. Vol. 33: 287-308. doi: https://doi.org/10.1016/j. jempfin.2015.03.004.

Mukherjee, T. K. \& Naka, A. (1995). Dynamic Relations between Macroeconomic Variables and the Japanese Stock Market: An Application of Vector Error Correction Model. The Journal of Financial Research. Vol. 18 (2): 223-235. doi: https://doi. org/10.1111/j.1475-6803.1995tb.00563.x.

Mustafa, K., Ahmed, R., \& Siddiqui, A. A. (2013). Money Supply and Equity Price Movements in Pakistan. European Journal of Business and Management. Vol. 5: 146157.

Sensarma, R., \& Bhattacharyya, I. (2016). Measuring Monetary Policy and Its Impact on The Bond Market of an Emerging Economy. Macroeconomics and Finance in Emerging Market Economies. Vol. 9(2): 109-130. doi: https://doi.org/10.1080/175 20843.2015.1123743.

Sharma, V. K., \& Sinha, C. (2006). The Corporate Debt Market in India. In: BIS (Eds.), Developing Corporate Bond Markets in Asia. BIS Paper No. 26: 80-87. 
Taboga, M. (2009). Macro-Finance VARs and Bond-risk Premia: A Caveat. Review of Financial Economics. Vol. 18(4): 163-171. doi: https://doi.org/10.1016/j. rfe.2009.06.002. 